\title{
'Getting under our skin': Introducing banked allograft skin to burn surgery in South Africa
}

\author{
N L Allorto, ${ }^{1}$ FCS (SA), MMed; A D Rogers, ${ }^{2}$ FC Plast Surg (SA), MMed; H Rode, ${ }^{3}$ FCS (SA), FRCS, MMed \\ ${ }^{1}$ Edendale Hospital Burn Service, Pietermaritzburg; and Department of Surgery, School of Clinical Medicine, College of Health Sciences, \\ Nelson R Mandela School of Medicine, University of KwaZulu-Natal, Durban, South Africa \\ ${ }^{2}$ Ross Tilley Burn Centre, Sunnybrook Health Sciences Centre, Toronto; and Division of Plastic and Reconstructive Surgery, Department of \\ Surgery, Faculty of Medicine, University of Toronto, Canada \\ Burn Unit, Red Cross War Memorial Children's Hospital, Cape Town; and Division of Paediatric Surgery, Department of Surgery, Faculty of \\ Health Sciences, University of Cape Town, South Africa
}

Corresponding author: A D Rogers (alandavid.rogers@sunnybrook.ca)

Deceased donor skin possesses many of the properties of the ideal biological dressing, and a well-stocked skin bank has become a critically important asset for the modern burn surgeon. Without it, managing patients with extensive burns and wounds becomes far more challenging, and outcomes are significantly worse. With the recent establishment of such a bank in South Africa, the challenge facing the medical fraternity is to facilitate tissue donation so that allograft skin supply can match the enormous demand.

S Afr Med J 2016;106(9):865-866. DOI:10.7196/SAMJ.2016.v106i9.10852

Burn injury remains a severely neglected epidemic in South Africa (SA), despite the magnitude of the problem. This has been described by a number of authors, and there is a shift towards addressing the deficits. ${ }^{[1-6]}$ The recent establishment of the first allograft skin bank in SA is potentially a tremendous stride towards moving in line with basic international burn care standards. Experience globally has shown that besides centralising burn care into regional multidisciplinary burn centres, the ready availability of deceased donor allograft skin has been the single most important strategy to reduce both mortality and morbidity. ${ }^{[7-14]}$

The gold standard for managing burn injuries remains excision and autografting using split-skin grafts. ${ }^{[7,11]}$ This skin is either meshed (to obtain greater surface area) or unmeshed (obligatory for hands and faces), depending on the recipient site, but requires available donor sites. Expansion ratios are seldom achieved: 2:1 does not gain $100 \%$ more skin coverage, for instance. Since certain areas are unsuitable as donor sites, $>50 \%$ burns may require repeated harvesting. Because donor sites heal by secondary intention, these areas require considerable physiological resources to heal, and several weeks before they are available for reharvest.
In addition, prolonged surgical interventions have been shown to increase the likelihood of intraoperative hypothermia, blood loss and other complications. As a result, when faced with a major burn, surgeons preferably excise and cover all areas with allograft as soon as possible. Once this is achieved, the patient will regain physiological equipoise, and autograft cover is no longer such an urgent priority, but can be performed in a staged, more effective manner. ${ }^{[8-11]}$

Allograft is also an excellent 'test of the wound bed'. If the skin 'takes', it is probable that the autograft will also take, therefore reducing the likelihood of autograft loss and optimising the critical resource that is the patient's donor sites. Further debridement can then be performed in sections where the allograft failed to adhere, for instance where debridement was inadequate, or in the presence of infection, fat necrosis, haematoma or seroma. ${ }^{[5-8]}$ Although the most important indication is undoubtedly in the context of the major burn, there are a number of other scenarios where an allograft may contribute substantial value in clinical practice (Table 1). ${ }^{[9,11]}$ Figs 1 - 3 demonstrate the advantage of sheet grafting a dorsal hand burn after debridement, prior to

Table 1. Major indications for deceased-donor allograft

\begin{tabular}{ll}
\hline Indication & Benefits and application \\
\hline Major burn & $\begin{array}{l}\text { Staged application at debridement, and staged removal when autograft or dermal substitute is to be placed } \\
\text { Alexander (sandwich) technique: }{ }^{[12]} \text { the application of widely meshed autograft covered by allograft }\end{array}$ \\
Small burn injury & $\begin{array}{l}\text { Uncertain depth of excision } \\
\text { Infection, e.g. burn wound cellulitis }\end{array}$ \\
& Hand and facial burns to optimise sheet autograft take (Figs 1 - 3) \\
Necrotising soft-tissue infection & Test the wound bed prior to autografting \\
Exfoliative skin conditions, e.g. toxic & Avoid repeated and painful dressing changes \\
epidermal necrolysis & Biobrane is regarded as the first line for this indication \\
Neoplasm & After excision, awaiting confirmation of adequate margins by pathology service \\
Complex wound from any cause & Test the wound bed prior to autografting
\end{tabular}




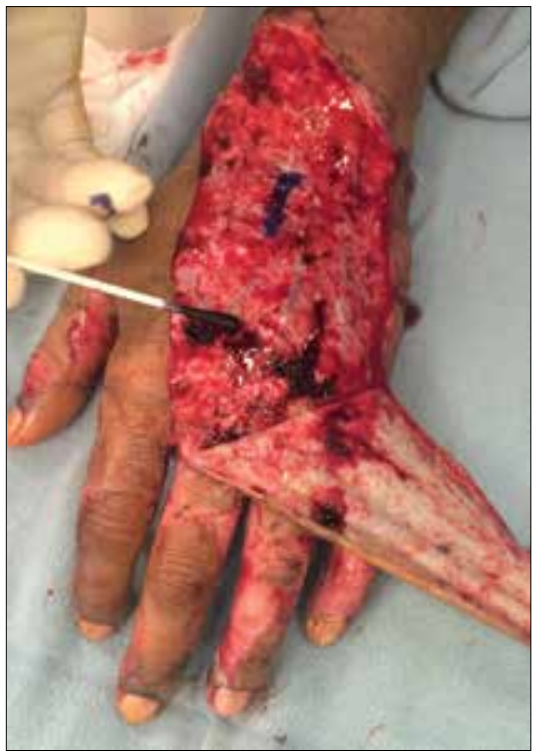

Fig. 1. Removal of sheet allograft; areas marked where further debridement is necessary.

autografting, to optimise graft take, reduce scarring and therefore optimise function.

Burn surgeons will only be able to take advantage of this strategy if there are adequate stores of skin, and this will require a significant alteration in the referral system of tissue donors, improved knowledge of the referral process on the part of healthcare professionals, and their participation in it, and the fostering of a culture of tissue donation in our society. ${ }^{[1,14,15]}$ Despite declining surgical numbers, organ transplantation is well established in $\mathrm{SA}^{\left[{ }^{[14,15]}\right.}$ in fact, it is internationally acclaimed. Tissue donation, however, is largely unknown as far as the general public and medical fraternity is concerned, with only corneal donation receiving some, albeit insufficient, attention. The few published data in this area locally focus on legal considerations. ${ }^{[15]}$ No effective system exists in state hospitals for the referral of potential tissue donors, and tissue (and organ) donations are predominantly derived from private hospitals. Although attitudes towards tissue donation are generally positive when information is provided, individuals are frequently reluctant to consider donating

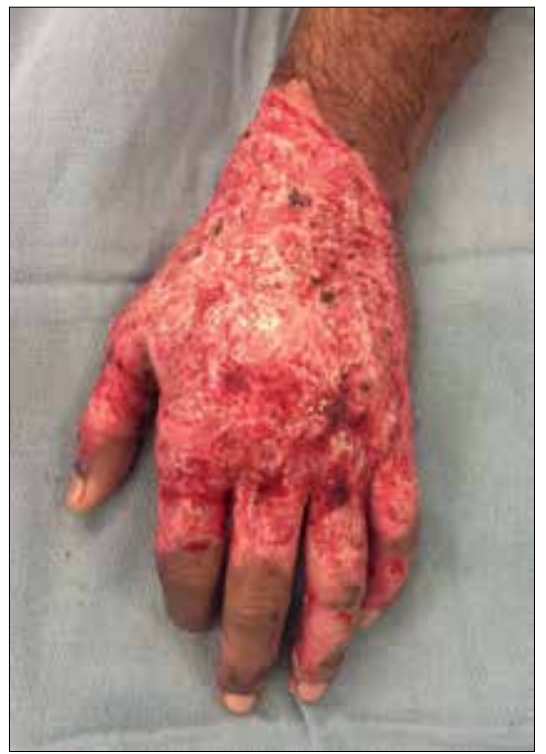

Fig. 2. Wound bed after selected further debridement.

the organs of a relative if they do not know that person's donation preference. ${ }^{[14]}$

It is apparent that campaigns need to be initiated that are inclusive of organs and tissue, and that target both the private and state healthcare sectors. There needs to be a collaborative effort to develop systems in hospitals for referral of tissue donors to the tissue bank (for skin, cornea, bone and heart valves), facilitation of education in all institutions, as well as a national campaign to create awareness of the value of tissue and organ donation. Only then will there be enough allograft skin in the bank to service the enormous number of burn patients requiring an allograft and for whom it will be potentially lifesaving, and the more than 60 other lives per deceased donor that can be enhanced through the application of allograft cornea, heart valves and bone.

1. Rode H, Berg A, Rogers A. Burn care in South Africa. Ann Burns Fire Disasters 2011;24(1):7-8.

2. Rogers $\mathrm{AD}$, Price $\mathrm{CE}$, Wallis $\mathrm{L}$, Rode $\mathrm{H}$. Towards a national burns disaster plan. S Afr J Surg 2012;49(4):174-177.

3. Allorto NL, Zoepke S, Clarke DL, Rode H. Burn surgeons in South Africa: A rare species. S Afr Med J 2016;106(2):186-188. DOI:10.7196/SAMJ.2016.v106i2.9954

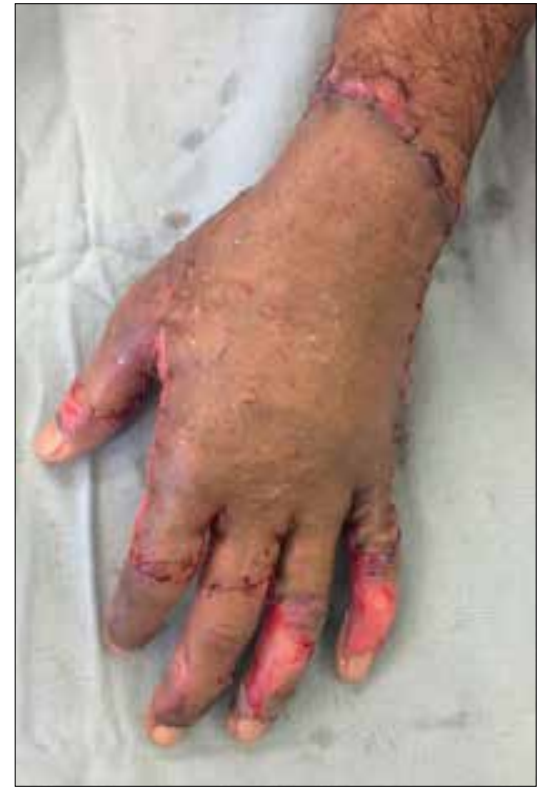

Fig. 3. Sheet autografting.

4. Rode H, Rogers AD, Numanoglu A, et al. A review of primary and secondary burn services in the Western Cape, South Africa. S Afr Med J 2015;105(10):853-857. DOI:10.7196/SAMJnew.8187

5. Rode H, Rogers A, Adams S, et al. The dilemma of treating major burns in South Africa. S Afr Med J 2013;103(9):608-609. DOI:10.7196/SAMJ.7361

6. Rogers $\mathrm{AD}$, Allorto NL, Wallis LA, Rode H. The Emergency Management of Severe Burns course in South Africa. S Afr J Surg 2013;51(1):38. DOI:10.7196/SAJS.1309

7. Janžekovič Z. A new concept in the early excision and immediate grafting of wounds. J Trauma 1970;10(12):11031108. DOI:10.1097/00005373-197012000-00001

8. Kagan RJ, Winter R, Robb EC. The skin bank. In: Herndon Kagan RJ, Winter R, Robb EC. The skin bank. In: Herndon
DN, ed. Total Burn Care, 4th ed. Edinburgh: Saunders Elsevier, DN, ed. Total

9. Leon-Villapalos J, Eldariri M, Dziewulski P. The use of human deceased donor skin allograft in burn care. Cell Tissue Bank 2010;11(1):99-104. DOI:10.1007/s10561-009-9152-1

10. Chua A, Song C, Chai A, et al. The impact of skin banking and the use of cadaveric skin allografts for severe burn victims in Singapore. Burns 2004;30(7):696-700. DOI:10.1016/j.burns.2004.03.016

1. Rogers $\mathrm{AD}$, Allorto $\mathrm{NL}$, Rode $\mathrm{H}$. Isn't it time for a cadaver skin bank in South Africa? Ann Burns Fire Disasters 2013;26(3):142-146.

12. Alexander JW, MacMilan BG, Law E, et al. Treatment of severe burns with widely meshed skin autograft and meshed skin autograft overlay. J Trauma 1981;21(6):433-438.

13. Atiyeh BS, Hayek SN, Gunn SW. New technologies for burn Atiyeh BS, Hayek SN, Gunn SW. New technologies for burn
wound closure and healing: Review of the literature. Burns 2005;31(8):944-956. DOI:10.1016/j.burns.2005.08.023

14. Etheredge HR, Turner RE, Kahn D. Attitudes to organ donation Etheredge $\mathrm{HR}$, Turner $\mathrm{RE}$, Kahn $\mathrm{D}$. Attitudes to organ donation
among some urban South African populations remain unchanged: A cross-sectional study (1993 - 2013). S Afr Med J 2014;104(2):133-137. DOI:10.7196/SAMJ.7519

15. McQuoid-Mason D. Human tissue and organ transplant provisions: Chapter 8 of the National Health Act and its Regulations, in effect from March 2012 - what doctors must know. S Afr Med J 2012;102(9):733-735. DOI:10.7196/SAMJ.6047

Accepted 11 April 2016 